$12-1-2020$

\title{
Senior Woman Administrators' Perceptions and Experiences of Women Serving in Leadership Positions in Conference Offices
}

Kelly Patricia Elliott

Coastal Carolina University, kelliott@coastal.edu

Tim Kellison

Georgia State University

Follow this and additional works at: https://trace.tennessee.edu/jasm

Part of the Education Commons, Social and Behavioral Sciences Commons, and the Sports Management Commons

\section{Recommended Citation}

Elliott, Kelly Patricia and Kellison, Tim (2020) "Senior Woman Administrators' Perceptions and Experiences of Women Serving in Leadership Positions in Conference Offices," Journal of Applied Sport Management: Vol. 12 : Iss. 2.

https://doi.org/10.7290/jasm120201

Available at: https://trace.tennessee.edu/jasm/vol12/iss2/1

This article is brought to you freely and openly by Volunteer, Open-access, Library-hosted Journals (VOL Journals), published in partnership with The University of Tennessee (UT) University Libraries. This article has been accepted for inclusion in Journal of Applied Sport Management by an authorized editor. For more information, please visit https://trace.tennessee.edu/jasm. 


\title{
Senior Woman Administrators' Perceptions and Experiences of Women Serving in Leadership Positions in Conference Offices
}

\author{
Kelly Patricia Elliott \\ Tim Kellison
}

\begin{abstract}
NCAA conference office Senior Woman Administrators (SWAs) were surveyed to gain their perspective on the gender disparity reported in intercollegiate athletics. The perceptions offered by the SWAs indicate the need for NCAA conference offices to implement professional development programming for women aimed at increasing management skills, developing best practice guidelines for including SWAs in athletic administration, and establishing mentor programs for women working on member institution campuses. Additionally, the results indicate directors of athletics need to create more meaningful opportunities for women to participate in decision making and include SWAs in meetings with coaches and other staff members.
\end{abstract}

Keywords: Women, leadership, intercollegiate athletics, administration, social role theory

Kelly Patricia Elliot is an assistant professor in the Department of Recreation and Sport Management at Coastal Carolina University.

Tim Kellison is as associate professor in the Department of Kinesiology and Health at Georgia State University.

Please send correspondence to Kelly Patricia Elliott, kelliott@coastal.edu 


\section{Introduction}

An analysis of the make-up of conference office staff in the National Collegiate Athletic Association (NCAA) membership indicates there are varying levels of involvement of women serving in positions at the conference office level. An analysis of the conference office senior leadership staff by gender presented in Table 1 shows that the higher the division designation, the higher percent of males made up the leadership team. This indicates there might be some barriers keeping women in these lower divisions of intercollege athletics. Additionally, an analysis of the conference office senior leadership staff by position, presented in Table 2 , indicates majority female involvement in the compliance and student-athlete advisory committee (SAAC) roles in smaller, Division II (DII) and Division III (DIII) conferences.

\section{Table 1}

Conference Office Senior Leadership by Gender

Division

Position

\section{Number Number of Men of Women in Position in Position}

NCAA

Division I FBS

NCAA Division I FBS

NCAA Division I FBS

NCAA Division I FCS
Senior

Associate Commissioner

Associate Commissioner

Assistant Commissioner

Senior Associate

Commissioner

NCAA Division I FCS

NCAA Division I FCS

NCAA Division I NoFB
Associate Commissioner

Assistant Commissioner

Senior Associate

Commissioner
Associate Commissioner

Assistant Commissioner

Associate Commissioner

Assistant Commissioner

Assistant Commissioner
18

30

19

4

15

15

7

6

9

11

10

4

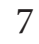

6

10

4

$13 \quad 11$

9

14

12

13

13

Note. FBS $=$ Football Bowl Subdivision; FCS $=$ Football Championship Subdivision; NoFB = No Football Subdivision 
Elliott and Kellison

\section{Table 2}

Conference Office Senior Leadership Positions by Gender

Division

Position

$\begin{array}{cc}\begin{array}{c}\text { Number } \\ \text { of Men }\end{array} & \begin{array}{c}\text { Number } \\ \text { of Women }\end{array} \\ \text { in Position } & \text { in Position }\end{array}$

NCAA Division I FBS

NCAA Division I FBS

NCAA Division I FBS

NCAA Division I FBS

NCAA Division I FCS

NCAA Division I FCS

NCAA Division I FCS

NCAA Division I FCS

Commissioner

Senior Compliance Officer

1

Senior Sport Information

SAAC Liaisons

$\begin{array}{rr}9 & 1 \\ 6 & 4 \\ 10 & 0 \\ 7 & 3 \\ 6 & 7 \\ 7 & 6 \\ 12 & 1 \\ 2 & 9 \\ 9 & 4 \\ 3 & 9 \\ 11 & 1 \\ 3 & 7 \\ 20 & 4 \\ 3 & 21 \\ 19 & 5 \\ 0 & 15 \\ 25 & 18\end{array}$

NCAA Division I NoFB

Commissioners

Senior Compliance Officer

Senior Sport Information

SAAC Liaisons

Commissioners

NCAA Division I NoFB

NCAA Division I NoFB

NCAA Division I NoFB

Senior Compliance Officer

Senior Sport Information

NCAA Division II

SAAC Liaisons

Commissioners

Senior Compliance Officer

Senior Sport Information

SAAC Liaisons

NCAA Division III

Commissioner

Note FBS $=$ Football Bowl Subdivision; FCS = Football Championship Subdivision; NoFB = No Football Subdivision

The trends presented in the tables above expand upon research reported by ESPN that women are more frequently at the helm of NCAA Division III athletic departments and less frequently at the NCAA Division I athletic director position (Voepel, 2017). However, a more recent study indicated women were finding success securing positions as conference commissioners at the NCAA Division I level (Taylor et al., 2018). As the gender disparity can be noticed both at the NCAA conference and member institution level, it is vital to gain insight into why such a disparity exists in the first place, as well as how the gender gap could be narrowed. In the study from Taylor et al., current NCAA Division I conference commissioners indicated barriers and stereotypes are realities for women entering the position. Additional insight from more women working in conference offices could expand upon these findings and add additional perspective of the reasons that underlie gender disparity in intercollegiate athletics.

The purpose of this study is to analyze perceptions and experiences from current women leaders working at conference offices. This context can be an impor- 
tant focus of inquiry because, similar to those made at the NCAA national office, many of the decisions made at conference offices trickle down to the institutional level. Practitioners can use the insight of senior-level women working in athletic conferences, as conferences work with multiple member institutions and have a "bird's-eye" view of the current landscape of women working on campus.

\section{Review of Literature}

Social role theory lays the groundwork for this study as it can be used to explain how women working in intercollegiate athletics have fallen into their expected roles in their organization. As the basis of social role theory, gender roles are defined as "those shared expectations about appropriate conduct that apply to individuals solely on the basis of their socially identified sex" (Eagly \& Wood, 1988 , p. 4). As these gender roles pertain to intercollegiate athletics, social role theory would indicate how men and women assigned to different roles in the athletic department will behave in the workplace's social space. This perspective has been identified in previous intercollegiate athletics research as women athletes view careers in athletics as masculine, thereby leading them to conclude those career paths to be unrealistic (Madsen, 2016).

Barriers impeding the advancement of women in intercollegiate have been studied from multiple perspectives to include understanding the "boys club" mentality (Hancock \& Hums, 2016; Melton \& Cunningham, 2014; Stier et al., 2010; Taylor \& Wells, 2017), the unintended consequences and perception of the SWA role (Hancock \& Hums, 2016; Hoffman, 2010; Lance et al., 2009), and the perceptions of a woman's ability to serve at the helm of an athletic department (Loggins \& Schneider, 2015; Taylor \& Hardin, 2016). When women can break through these barriers and gain a position the helm of a Division I (DI) athletic department, they may be met with increased scrutiny and criticism (Taylor \& Hardin, 2016).

Although there have been barriers identified for women working in the field of intercollegiate athletics, previous research has also found the perception of barriers prevent women from pursuing career aspirations in the sport industry (Leberman \& Shaw, 2012; Taylor \& Hardin, 2016). Additionally, the lack of women mentors has been found to prevent the advancement of women in intercollegiate athletics (Taylor \& Hardin, 2016). However, benefits of mentoring women working in intercollegiate athletics have also been studied indicating the value of the practice (Hancock, 2017; Hancock et al., 2017; Hancock \& Hums, 2016).

When women think about advancement in their careers, many acknowledge that they wanted to stay in roles in intercollegiate athletics that aligned with their professional interests (Hancock \& Hums, 2016). One such interest is the maintaining of connections to student-athletes, which some fear could be lost if they were to advance to more senior level roles. Women report valuing the role they play in the development of student-athletes (Hancock \& Hums, 2016). 
The SWA role has also been extensively studied in existing literature. The designation was originally intended to give women opportunities in the NCAA leadership. Even so, there has been a reported disparity between how SWAs perceive their involvement on campus and how athletic directors view the role (Lance et al., 2009; Tiell et al., 2012; Wilson, 2017).

The need to analyze the perceptions and experiences from current women leaders working at conference offices is apparent. Previous research has found women have found more success securing leadership positions at the conference office level in comparison to positions on member institution campuses (Taylor et al., 2018). Therefore, inquiry into the perceptions of women working in senior level positions in the conference offices could help provide practitioners an understanding of what could make the conference office different from member institution campuses.

\section{Methodology}

To explore the perceptions of women in senior-level positions at NCAA conference offices regarding their involvement during high-level decision making (in their conference office, and more generally, the involvement of women in the member institutions in which their conference offices serve), an electronic survey was distributed to 71 NCAA conference office SWAs. Email addresses for the SWAs were obtained from NCAA conference office websites, and each SWA was sent an email invitation containing information about the study, an informed consent statement, and a hyperlink to the online survey.

The study contained 21 questions containing both open- and close-ended items. Items were informed by Taylor et al. (2018)'s research regarding NCAA Division I female commissioners and centered around professional development opportunities, the prevalence of a "boys' club" environment, and the perceived benefit of the SWA designation. The survey items are listed in Appendix A. Content analysis of the qualitative responses was used to identify themes and patterns within the data. The coder used a data-driven coding process to ensure she did not bring predetermined themes into the coding process (Brinkmann, 2013). Additionally, the coder consulted with the study's coauthor throughout the coding process (Saldaña, 2016). To support interpretive validity, empirical material from the interview responses are reported entirely in the form of verbatims (Johnson \& Christensen, 2016).

The empirical material collected from the participants represent the feedback of high-level managers from the offices of NCAA conferences. The access to highlevel managers provides important insight into the current working environment for women (and men) working in athletic administration, and the accuracy and significance of the empirical material are strengthened by the expertise of these participants. 


\section{Results and Discussion}

In sum, 19 individuals across the three NCAA divisions responded to all openended items. SWAs from four DI conferences, 11 DII conferences, and four DIII conferences participated. Of the respondents, all but one had a graduate degree, and the majority held graduate degrees in Sport Management or a related field. The table in Appendix B includes a list of participants and their educational background. To conceal the identity of participants, pseudonyms for participants were used (Taylor, 2016). Throughout responses, themes of professional development, barriers for advancement, and the confusion surrounding the SWA designation were noted. These themes are highlighted in further detail below.

\section{Professional Development}

The importance of professional development opportunities for women working in the NCAA membership was a theme among respondents at all levels of NCAA membership. Although many SWAs noted they were able to attend all of the professional development events they wanted, others still indicated a lack of support. For instance, Christie reported there were still areas that could be improved: "Management training in personnel supervision would be most helpful, I think." Her response indicates that although women leaders are able to attend conferences and conventions, these events might not sufficiently provide the professional development opportunities many aspiring women leaders seek. Additionally, when it comes to women leaders on campus being helped by their conference offices, most SWAs indicated some sort of conference meetings (e.g., calls or in-person meetings) or the availability of funding to attend one of the professional development opportunities mentioned above. Shannon described the involvement of women in her conference:

The SWAs in our conference are part of the governance structure. They have a standing council that meets in person at least twice per year. They oversee the sportsmanship award within the conference as well as the Women in Athletics Seminar that we host annually. Institutions are encouraged to use NCAA conference grant funds for SWA professional development, and we run an [athletic director]/SWA mentor program for those SWAs interested in possibly becoming an [athletic director].

This narrative indicates that conferences are encouraging women to partake in the administrative and governance proceedings of the conference. As mentioned in previous literature, the lack of women mentors visible in intercollegiate athletics may contribute to the lower rates at which women aspire to serve as athletic directors (Taylor \& Harden, 2016). This situation indicates that at least at the conference level, there is an understanding of the importance of female mentors. Previous researchers have recommended that all individuals with decision making power, including men, provide these mentor opportunities (Taylor \&Wells, 2017). 
Many SWAs might not receive the proper training to take advantage of their designation on campus and in the conference office. As mentioned previously, the lack of professional development opportunities might prevent women from advancing in the field (Schneider et al., 2010). This problem can remain true if women are given new responsibilities without the proper training to be successful. One perspective shared by a Chloe was that SWAs were seen more as the "workhorse" on campus as opposed to having the opportunity to grow in the strategic planning process. She recommended that top administrators:

provide ways to extend their brand. Not just be the do-ers of the work, but the strategist as well. At many campuses, [SWAs] do more than the ADs in running the day to day but are not seen as leaders or given an opportunity to lead.

It is important to point out that some SWAs noted financial constraints prevented conference offices from providing additional professional development opportunities to women in their membership. Despite this constraint, Penelope offered a solution to this problem:

I believe there is a benefit to more regional programming. ...We have undertaken this initiative in the northeast and have been very successful. With limited budgets and time, it is sometimes difficult to travel and fully engage in national events and/or conventions. Regional travel can be more easily managed. It does not replace the need for national programming, but is a solid supplement-especially in those years in which attendance at national conventions is not possible.

It is imperative for conferences to explore additional possibilities to ensure their women leaders on campus are receiving access to meaningful professional development opportunities. As discussed above, a number of professional development initiatives exist across all levels, including the NCAA, conferences, and individual institutions. Despite these offerings, some trainings may be inadequate, and others may be difficult to access (especially because of budgetary constraints). Additional barriers are identified in the following section.

\section{Barriers for Women in Intercollegiate Athletics}

Senior-level administrators indicated a number of barriers that women faced when looking to advance in intercollegiate athletics. One pattern that emerged through the surveys was that respondents believed the "boys' club mentality" is losing steam. As noted by one SWA, this might be because there are more employees used to women holding the reins. However, a majority of SWAs reported experiencing at least some degree of a "boys' club mentality" during their time working at a conference office. Chelsea described her experience:

Yes, there is definitely a "male vibe" that myself and my fellow SWAs have to deal with in terms with getting a seat at the table. Often myself and the 
other female that works in our office are treated differently because of our gender.

Although not all SWAs in the study observed this phenomenon at the conference office, some reported seeing it at other times in the field. For example, Sarah discussed in detail how, despite her status as a senior-level administrator at the conference level, her qualifications were questioned by men from the conference's institutional members:

I haven't personally experienced this from within my office, but I do believe that other conference commissioners do not respect the SWA role in practice, based on how we are treated at meetings. I have experienced discrimination from certain entities we work with when my commissioner is unavailable. For example, the question was asked, "Who will deal with the baseball coaches on issues since Commissioner isn't there?" right after it was stated that I would be the site rep while my commissioner finished the softball championship. My boss has been nothing but supportive, however, of my professional development and my role within the office regardless of my gender.

This experience is consistent with previous research that has shown women are not perceived to be "ready" to run an athletic department (Hancock \& Hums, 2016). These findings suggest there is more training needed to clarify where the uncertainty is stemming from and how to change misperceptions related to women leaders in intercollegiate athletics.

Christie simply argued that intercollegiate athletics "[needs] more women in leadership roles to challenge status quo thinking." This statement is reflective of previous research showing the ability of the "boys' club mentality" to impede female leadership growth (Schneider et al., 2010). It is important for this to be addressed with the changing culture of intercollegiate athletics.

Additionally, reports from SWAs in the conference office are consistent with past research indicating the designation has been used as the "sole woman's administrator" rather than to fill a position on the senior management team (Hoffman, 2010). For example, Sarah explained:

I believe there must be consistent inclusion of SWAs (and minorities) in the decision-making process at the conference office level and athletics department level. Some SWAs are in title only and not in process. Over time, [the] situation I mentioned is no longer an issue because not only have I proven myself to those external organizations, but my boss includes me in those planning calls, site visits, and decision making. It is clear where I stand within our organization to those within it and outside of it.

This perception emerged through participant responses indicating women at the conference office level were included more in the governance process, but women working on campus may not be as involved in the governance process. One SWA 
indicated that she noticed women leaders on campus are still serving as party planners. This responsibility indicates there are still instances of women serving the more feminine roles in the athletic department.

The desire from these SWAs to have more of a role in governance is consistent with Grappendorf et al. (2008), whose research showed that as much as 10 years ago, SWAs expressed the desire to have larger roles in the decision-making process (Grappendorf et al., 2008). In light of this desire, Dannielle offered an argument for administrations to be more inclusive of women in senior leadership:

Understanding the unique perspective, a woman can add to big decisions [being made], and the value [her insights bring] to the student-athletes we serve. Nearly half or more of our student-athletes are women. We need to make decisions that benefit both sexes.

The results indicated that there are varying perspectives of SWAs, depending on the institution. As Christie indicated, the SWA role "varies by campus and the degree to which the leadership ( $\mathrm{AD}$ and President) involve/rely on the SWA for input and decision making." Although there is a varying degree of involvement of SWAs at the campus level, many women administrators at the conference office level reported institutions are attempting to hire more women into their department, but budgetary issues prevent institutions from hiring. Additionally, some institutions are finding it difficult to recruit the right women for the job. Sarah described her perspective of the SWA situation below:

I've seen this on our campuses in minute ways, but I've also seen them have a difficulty recruiting females to come of their campuses when hiring for specific positions. Within our athletic departments I think the effort is made but the lack of understanding on how to effectively implement the role can be muddled. Additionally, I think they also struggle to communicate the role of the SWA to external departments on campus and within their community.

This narrative indicates the role of women working in intercollegiate athletics varies largely from campus to campus.

\section{SWA Designation Confusion}

A third theme that emerged amongst respondents was the lack of clarity in the SWA designation, a designation intended to give women working in intercollegiate athletics more opportunities. Despite the confusion in the SWA role, the vast majority of SWAs in this study (more than 88\%) reported they still felt the designation is beneficial. With the common perception that the SWA designation still serves a purpose, it is important to clarify its purpose to both SWAs and their colleagues working in the administration of intercollegiate athletics.

Of the responses from SWAs, it was noted that many participants indicated the need for stronger marketing campaigns for the SWA role. Specifically, admin- 
istrators (at the NCAA and institutional levels) should clarify what the SWA designation should mean on college campuses. Lynn advised administrators to:

learn about the expectations from the NCAA about the SWA role, functions on campus, and generally why there is a SWA. I get too many questions from SWAs who aren't really sure what they should be doing or assisting with. [We] need to have some sort of mandatory re-education session for all administrators and campus leadership about required and highly recommended positions within an athletic department-start with the [Faculty Athletics Representative] and SWA positions and work through the list.

Additionally, there was a pattern of SWAs indicating the need for current women looking to advance in the leadership structure to volunteer in positions that were outside of their traditional areas. Patricia encouraged others to "try to get more involved in leadership on campus/at the conference level" and to "volunteer for additional responsibilities that will lead to more experience." However, despite the positive experiences that can benefit current women who volunteer in other aspects of the athletic department, there is limited time in the day. Chloe addressed this concern:

In my experience, many SWAs are in Compliance or Academic Affairs [departments]. I was SWA on my campus as [a sports information director]/media, which is unusual. Sometimes it's an athletic trainer as well. It's a weird mix of skill sets that often take on the role, making it difficult to find a clear way to promote. These are difficult roles to sometimes transition out of without business experience or sport oversight. ...The compliance person [volunteering] to learn other tasks sounds nice, but when would they have time to learn about marketing? They need to be at the table for budget meetings or coaching assessments to be able to learn these skills firsthand. These should be requirements that are included or highly recommended be provided to SWAs to allow them the opportunity to advance in their career and move out of their current role.

Despite the varying views on how women can get involved, the testimony of SWAs showed patterns of the role leading to opportunity, especially within the NCAA structure, as explained by Molly: "The SWA designation provides access to NCAA committees, conference meetings, and committees and the allocation of funds by the institution to support this model.'

Even with the perceived need for the designation, there is still some confusion over the actual degree or extent to which women leaders should be involved on campus or in the conference office, as discussed by Lynn:

There remains misunderstanding of the SWA and the role that individual fills for all student-athletes and the department's operation. I 
have some very good SWAs who are at institutions that "get it," but I also have member institutions that really don't know how to integrate the SWA or to utilize that role. It has gotten better since we incorporated the SWA into the conference governance structure. The conference provides opportunities to attend [Women Leaders in College Sports] convention/programs, NCAA Convention, NCAA Rules seminar for its SWAs through the Division III Strategic Initiative grant program.

This same thought process was shared when SWAs were asked how professional development could be improved on campus. Lucy agreed:

I think the biggest thing right now is simply helping to define what the SWA role is. The SWAs in our league all wear different hats and have different focus areas; they have the SWA title. Helping the women who have a seat at the table learn how to be prepared and be willing to use that time to be educated and confident-those are areas to continue to improve.

Although the majority of SWAs in the study report there was still a benefit to having the SWA designation on campus, there was considerably less agreement on what the requirements of the position should be for potential SWAs. Less than half of SWAs indicated there should be no requirements for SWAs. Currently, there is no minimum education or experience requirement for SWAs; however, some SWAs felt that this should not be the case. Victoria argued, "Individuals should have administrative duties, not just the only head female on the coaching staff, or an athletic trainer who does not serve in a leadership role on the campus." This sentiment was shared even among SWAs that believed there should not be stated requirements to the position. For example, Molly contended:

Because SWA is a designation and not a job, it is hard to put specific requirements. The one area of concern I have is female coaches being named the SWA and not being given any administrative duties. Since SWA is the senior female administrator, being named the SWA without administrative responsibilities should not occur.

With the lack of administrative duties found among institution SWAs, previous research is supported as SWAs are sometimes perceived in name only (Grappendorf et al., 2008). Given the growing representation of women in the field of intercollegiate athletics, it is important to reevaluate this SWA designation to fit the changing culture, ensuring the designation represents more than just a title.

Although the SWA designation was found to open doors for participants in this study, it is important to note that these doors seem to only open for women holding the SWA designation. This indicates that women must compete for the designation of SWA with other women in their department or conference, thus giving themselves the chance to participate in this type of professional development. This finding supports previous research that women create barriers for each other (Hancock \& Hums, 2016). 


\section{Concluding Remarks}

Practitioners can use the suggestions and insight from the SWAs in this study to help create more meaningful opportunities for women working in intercollegiate athletics. Relating to Social Role Theory, the results indicate it might be necessary for NCAA leadership to rethink the SWA designation, as this position might be seen as women fulfilling their perceived gender roles and possibly prevent the advancement of other women. The SWAs in this study indicated they notice SWAs on some campuses do not have the opportunities to participate in operation or administrative activities on campus; they serve the role in title only. The designation might not be helping women completely overcome the perceived norm and forge a path themselves to higher administrative and leadership positions

Although participants in this study identified the availability of professional development opportunities, it was a common perception that these professional development opportunities were not always giving women the necessary education and experience to learn the skills necessary to participate meaningfully in athletics-related decision making and secure higher positions in their organizations. Leaders in the FBS conferences are perceived to be more "powerful" in the membership, and men might be thought of as a better fit for these roles because of the perceived directive leadership style they bring to the table, thus making them seem more effective (Eagly \& Karau, 2002). Without the proper education and experience, it could prove difficult to see any meaningful change. Practical implications resulting from the perceptions of SWAs presented in this manuscript are included in Table 3 below.

\section{Table 3}

\section{Practical Implications}

NCAA Conferences implement professional development programming for women aimed at increasing management skills.

NCAA Conferences develop best practice guidelines for member institutions to ensure SWAs are involved in athletic administration.

NCAA Conferences conduct gender and diversity training for all member institution senior level administrators.

NCAA Conferences establish mentor program for women serving in athletic leadership positions on member institution campuses.

Directors of Athletics create meaningful opportunities for women in the athletic department to participate in decision making.

Directors of Athletics include women designated as the SWA in meetings with coaches and other staff to ensure athletic department understands the role of the SWA. 
This research analyzed perspectives from women leaders at the conference office level of NCAA membership; however, future research can seek responses from women working in the campus level of NCAA membership. In this study, SWAs perceived their experiences as conference-level administrators to be different from those working on campuses. In future research, scholars can identify differences and further evaluate what women working in leadership positions on campus perceive to be the perceptions and experiences of women working in intercollegiate athletics.

\section{References}

Brinkmann, S. (2013). Qualitative interviewing. Oxford University Press. Eagly, A. H. \& Karau, S. J. (2002). Role congruity theory of prejudice toward female leaders. Psychological Bulletin, 108, 573-598.

Eagly, A. H., \& Wood, W. (1988). Explaining sex differences in social behavior: A meta-analytic perspective. Paper presented at American Psychological Association Conference, Atlanta, GA.

Grappendorf, H., Pent, A., Burton, L., \& Henderson, A. (2008). Gender role stereotyping: A qualitative analysis of senior woman administrators' perceptions regarding financial decision making. Journal of Issues in Intercollegiate Athletics, $1,26-45$.

Hancock, M. G., Grappendorf, H., Wells, J. E., \& Burton, L. (2017). Career breakthroughs of women in intercollegiate athletic administration: What is the role of mentoring? Journal of Intercollegiate Sport, 10, 184-206.

Hancock, M. G., \& Hums, M. A. (2016). A "leaky pipeline"?: Factors affecting the career development of senior-level female administrators in NCAA Division I athletic departments. Sport Management Review, 19, 198-210.

Katz, M., Walker, N. A., \& Hindman, L. C. (2018). Gendered leadership networks in the NCAA: Analyzing affiliation networks of senior woman administrators and athletic directors. Journal of Sport Management, 32, 135-149.

Lance, L. M., \& Drummond, J. L. (2009). The perceived role of senior women administrators in NCAA Division I institutions. The Sport Journal.

Leberman, S., \& Shaw, S. (2012). Preparing females sport management students for leadership roles in sport. Regional Hub Project, 1, 1-41.

Loggins, R., \& Schneider, L. (2015). Exploring issues and trends of women and minorities in athletic administration. KAHPERD Journal, 52, 32-36.

Madsen, R. (2016). "Dads play basketball, moms go shopping!" Social role theory and the preferences for male coaches. Journal of Contemporary Athletics, 10, 277-291.

Melton, N. E., \& Cunningham, G. B. (2014). Examining the workplace experiences of sport employees who are LGBT: A social categorization theory perspective. Journal of Sport Management, 28, 21-33.

Saldaña, J. (2016). The coding manual for qualitative researchers (3rd ed.). SAGE Publications Ltd. 
Stier, W. F., Schneider, R. C., Henry, T. J., \& Wilding, G. E. (2010). Equity and discrimination in NCAA athletic departments: Perceptions of senior women administrators. Ghana Physical Education and Sport Journal, 1, 46-58.

Taylor, E. A., \& Hardin, R. (2016). Female NCAA Division I athletic directors: Experiences and challenges. Women in Sport and Physical Activity, 24, 14-25.

Taylor, E. A., Siegele, J. L., Smith, A. B., \& Hardin, R. (2018). Applying career construction theory to female National Collegiate Athletic Association division I conference commissioners. Journal of Sport Management, 32, 321-333.

Taylor, E. A., \& Wells, J. E. (2017). Institutionalized barriers and supports of female athletic directors: A multilevel perspective. Journal of Intercollegiate Sport, 10, 157-183.

Tiell, B., Dixon, M. A., Yin, Y. (2012). Roles and tasks of the senior woman administrator in role congruity theory perspective: A longitudinal progress report. Journal of Issues in Intercollegiate Athletics, 5, 247-268.

Voepel, M. (2017, June 30). Women in athletic departments: Welcomed or marginalized? ESPN. https://www.espn.com/espnw/culture/feature/story/_/ id/19686799/women-athletic-departments-welcomed-marginalized

Wells, J. E., \& Kerwin, S. (2017). Intentions to be an athletic director: Racial and gender perspectives. Journal of Career Development, 44, 127-143.

Wilson, A. (2017). Optimization of the senior woman administrator designation. http://www.ncaa.org/sites/default/files/2018SWA_17-NCAA-1984_InclusionsSWAReport-20180402.pdf 